\title{
Isolation, Characterization, and Sensitivity to 2,4-Diacetylphloroglucinol of Isolates of Phialophora spp. from Washington Wheat Fields
}

\author{
Youn-Sig Kwak, Peter A. H. M. Bakker, Debora C. M. Glandorf, \\ Jennifer T. Rice, Timothy C. Paulitz, and David M. Weller
}

First and fourth authors: Department of Plant Pathology, Washington State University, Pullman 99164-6430; second author: Plant-Microbe Interactions, Department of Biology, Utrecht University, Padualaan 8, $3584 \mathrm{CH}$ Utrecht, The Netherlands; third author: GMO Office, Expert Centre of Substances, National Institute for Public Health and the Environment, P.O. Box 1, 3720 BA Bilthoven, The Netherlands; and fifth and sixth authors: United States Department of Agriculture-Agricultural Research Service, Root Disease and Biological Control Research Unit, Pullman, WA 99164-6430.

Current address of Y.-S. Kwak: Biology Department, Brookhaven National Laboratory, Upton, NY 11973.

Accepted for publication 6 January 2010.

\begin{abstract}
Kwak, Y.-S., Bakker, P. A. H. M., Glandorf, D. C. M., Rice, J. T., Paulitz, T. C., and Weller, D. M. 2010. Isolation, characterization, and sensitivity to 2,4-diacetylphloroglucinol of isolates of Phialophora spp. from Washington wheat fields. Phytopathology 100:404-414.

Dark pigmented fungi of the Gaeumannomyces-Phialophora complex were isolated from the roots of wheat grown in fields in eastern Washington State. These fungi were identified as Phialophora spp. on the basis of morphological and genetic characteristics. The isolates produced lobed hyphopodia on wheat coleoptiles, phialides, and hyaline phialospores. Sequence comparison of internal transcribed spacer regions indicated that the Phialophora isolates were clearly separated from other

trees of the avenacinase-like gene in the Phialophora spp. also clearly separated them from other Gaeumannomyces spp. The Phialophora isolates were moderately virulent on wheat and barley and produced confined black lesions on the roots of wild oat and two oat cultivars. Among isolates tested for their sensitivity to 2,4-diacetylphloroglucinol (2,4-DAPG), the $90 \%$ effective dose values were 11.9 to $48.2 \mu \mathrm{g} \mathrm{ml}^{-1}$. A representative Phialophora isolate reduced the severity of take-all on wheat caused by two different isolates of Gaeumannomyces graminis var. tritici. To our knowledge, this study provides the first report of an avenacinase-like gene in Phialophora spp. and demonstrated that the fungus is significantly less sensitive to 2,4-DAPG than G. graminis var. tritici.
\end{abstract} Gaeumannomyces spp. Primers AV1 and AV3 amplified 1.3-kb portions of an avenacinase-like gene in the Phialophora isolates. Phylogenetic
Additional keywords: take-all decline.
The Gaeumannomyces-Phialophora (G-P) complex consists of Gaeumannomyces graminis (Sacc.) Arx \& D. L. Olivier, related anamorphic Phialophora spp., and other Gaeumannomyces spp. found on grasses and cereal roots $(3,11,13)$. G. graminis has four varieties: tritici, avenae, graminis, and maydis. All varieties produce similar diseases on wheat, oat, rice, and corn, respectively, and can have Phialophora-like anamorphs. Species and varieties in the G-P complex have distinct morphological characteristics; however, identification of each can be time consuming and, at times, inconclusive because morphological traits overlap among the fungi $(7,10,11,13)$. However, the type of hyphopodia formed is a key trait by which members of this complex are differentiated. A variety of molecular techniques have been developed to facilitate identification of fungi in the G-P complex; for example, restriction fragment length polymorphism using the internal transcribed spacer (ITS) and 18S rDNA genes $(11,13)$, random amplified polymorphic DNA analysis (10), polymerase chain reaction (PCR) assays based on nuclear rDNA (9) or avenacinase

Corresponding author: D. M. Weller; E-mail address: wellerd@wsu.edu

* The $\boldsymbol{e}$-Xtra logo stands for "electronic extra" and indicates that Figures 2, 3, and 4 appear in color online.

doi:10.1094/PHYTO-100-5-0404

This article is in the public domain and not copyrightable. It may be freely reprinted with customary crediting of the source. The American Phytopathological Society, 2010. and avenacinase-like gene sequences (26), and sequence and phylogenetic analysis of the ITS regions (2). Collectively, these molecular techniques have revealed considerable diversity within the G-P complex.

Take-all, caused by G. graminis var. tritici J. Walker, is both the most important disease caused by G. graminis and one of the most important root disease of wheat worldwide $(3,11)$. Wheat is highly susceptible to $G$. graminis var. tritici, but other members of the Poaceae (e.g., barley, rye, and triticale) are also susceptible. In the Pacific Northwest, past surveys have demonstrated that takeall is present in most wheat fields $(12,27)$, even in areas with as little as 250 to $300 \mathrm{~mm}$ of annual precipitation $(3,4)$. Wheat grown in the high-rainfall areas west of the Cascade Mountains and under irrigation exhibits "textbook" symptoms of take-all, including diseased plants in patches, whiteheads, and blackened stem bases. However, symptoms typical of "dryland take-all" usually occur on wheat in the dryer intermountain Pacific Northwest (3).

Crop rotation and tillage are effective methods to control takeall. However, in the Pacific Northwest, the trends are toward reduced tillage and two or more crops of wheat or barley before a break to a nonhost crop; these practices exacerbate the incidence and severity of the disease. Take-all is also controlled by take-all decline (TAD), a worldwide phenomenon characterized by a spontaneous decrease in disease incidence and severity following a severe outbreak of take-all $(3,33,34)$. In Washington State and The Netherlands, a build-up of populations of 2,4-diacetylpholo- 
glucinol (2,4-DAPG)-producing Pseudomonas fluorescens $\left(\mathrm{phlD}^{+}\right)$ and production of 2,4-DAPG on roots during wheat monoculture were shown to be responsible for TAD (34).

In a recent survey of TAD and non-TAD fields in Washington State, we reported that isolates of $G$. graminis var. tritici are highly sensitive to $2,4-\mathrm{DAPG}\left(90 \%\right.$ effective dose $\left[\mathrm{ED}_{90}\right]$ values $=$ 3.1 to $11.1 \mu \mathrm{g} \mathrm{ml}^{-1}$ ), and exposure of the pathogen to the antibiotic in TAD fields over multiple growing seasons did not result in the buildup of tolerance (14). During that survey, we isolated fungi from roots of wheat that appeared to be part of the G-P complex and previously were not known to be present in Washington State fields.

The objectives of this study were to characterize these unknown G-P complex isolates by using classical and molecular approaches and to begin to determine their role in the biology of take-all in the Pacific Northwest. We focused on determining the distribution of these fungi in Washington fields, their sensitivity to 2,4-DAPG, and their ability to cause take-all-like symptoms on cereal crops.

\section{MATERIALS AND METHODS}

Fungal isolates, media, and storage. Strains of G. graminis var. tritici used as controls in this study were from Washington wheat grown during the last 30 years. For example, strain R3111a-1 was isolated in 1980 from a TAD field near Moses Lake and strain ARS-A1 was isolated in 1990 from the United States Department of Agriculture-Agricultural Research Service (USDA-ARS) Palouse Conservation Field Station near Pullman. Strains MV116 and MV119 were isolated in 1987 from near Mount Vernon, and L116 (isolated in 1987) and LD5 and LDP21 (both isolated in 2007) were from the Lind TAD field on the Washington State University (WSU) Lind Dryland Research Station. G. graminis var. tritici and unknown G-P complex isolates were cultured on one-fifth-strength potato dextrose agar (1/5× PDA): potato dextrose broth (4.5 g) (PDB) (BD, Sparks, MD), agar (20 g) (Sigma-Aldrich, St. Louis), and water (1 liter). A semiselective medium for G. graminis var. tritici (R-PDA) (5) was used to isolate all G-P complex isolates from roots. For RPDA, peeled potato slices ( $40 \mathrm{~g}$ ) were boiled for $10 \mathrm{~min}$ and the filtered extract was increased to a volume of 1 liter with water. Dextrose $\left(4 \mathrm{~g} \mathrm{liter}^{-1}\right)$ and agar $\left(18 \mathrm{~g} \mathrm{liter}^{-1}\right)$ were added and the $\mathrm{pH}$ was adjusted to 6.5 before autoclaving. Rifampicin $(100 \mu \mathrm{g}$ $\mathrm{ml}^{-1}$ ) (Sigma-Aldrich) and Rizolex (Tolclofos Methyl; purity = 98\%) $\left(1 \mu \mathrm{g} \mathrm{ml}^{-1}\right)$ (Chem Services, West Chester, PA) were added after autoclaving when the medium cooled.

G-P complex fungi were stored by several different methods. For example, strains R3-111a-1 and ARS-A1 were stored at $4{ }^{\circ} \mathrm{C}$ on $1 / 5 \times$ PDA amended with rifampicin $\left(100 \mu \mathrm{g} \mathrm{ml}^{-1}\right)$. Once a year, each strain was taken out of storage, cultured on 1/5× PDA, and tested for virulence on wheat as described below to insure that it remained highly virulent. Each strain was reisolated from diseased roots, grown on $1 / 5 \times$ PDA with rifampicin $\left(100 \mu \mathrm{g} \mathrm{ml}^{-1}\right)$, and again placed at $4^{\circ} \mathrm{C}$. Strains MV116, MV119, and L116 were stored as hyphal fragments in $20 \%$ glycerol at $-80^{\circ} \mathrm{C}$. Isolates collected during this current study were stored on slants of $1 / 5 \times$ PDA in glass screw-cap tubes with and without mineral oil, and as colonized plugs of $1 / 5 \times$ PDA in autoclaved distilled water in glass tubes (8) in the dark at room temperature.

Isolation and culture of fungi. We isolated G-P complex fungi from wheat grown in fields located on commercial or research farms in central and eastern Washington, northern Idaho, and Montana, and from native grasses growing in noncropped (virgin) sites near these fields (Table 1). The Pullman TAD field (PD) is located on the USDA-ARS Palouse Conservation Field Station near Pullman, WA (24) and has been direct seeded to wheat or barley for 22 years. The Pullman conducive (PC) field is located $50 \mathrm{~m}$ from the PD field, had a history of crop rotation, is conducive to take-all, and, in recent times, has been direct seeded. The Pullman virgin (PV) site is adjacent to the PC field. The Almota TAD (ADB) field is located on a farm near the Port of Almota, WA, has been direct seeded for $>20$ years, and was cropped to corn for seven continuous years followed by 4 years of continuous wheat. The Almota rotation (ALR) field is located on a farm near the Port of Almota. The Ritzville TAD (RD) field is located on a farm near Ritzville, WA. It is irrigated, conven-

TABLE 1. Cropping history of fields and geographic origin of isolates of Gaeumannomyces graminis var. tritici and putative Phialophora spp.

\begin{tabular}{|c|c|c|c|c|c|}
\hline Field $^{\mathrm{a}}$ & $\begin{array}{c}\text { No. of } \\
\text { Gaeumannomyces/Phialophora }^{\mathrm{b}}\end{array}$ & Cropping history $^{\mathrm{c}}$ & Host & $\begin{array}{l}\text { Management } \\
\text { practices }^{\mathrm{d}}\end{array}$ & $\begin{array}{l}\text { Soil suppressive } \\
\text { to take-all }\end{array}$ \\
\hline Pullman TAD (PD) & $1 / 18$ & 22 years wheat or barley & Wheat & NT, NI & + \\
\hline Pullman conducive (PC) & $13 / 0$ & Crop rotation & Wheat & NT, NI & - \\
\hline Pullman virgin (PV) & $1 / 0$ & Noncropped & Grass & NI & - \\
\hline Ritzville TAD (RD) & $46 / 0$ & 3 years wheat & Wheat & CT, I & + \\
\hline Lind TAD (LD) & $40 / 0$ & 40 years wheat & Wheat & CT \& RT, I & + \\
\hline Lind virgin (LV) & $30 / 0$ & Noncropped & Grass & $\mathrm{NI}$ & - \\
\hline Lind TAD patch $(\mathrm{LDP})^{\mathrm{e}}$ & $30 / 0$ & 40 years wheat & Wheat & CT \& RT, I & + \\
\hline Almota TAD (ADB) & $18 / 6$ & 7 years corn, 4 years wheat & Wheat & $\mathrm{NT}, \mathrm{NI}$ & + \\
\hline Quincy virgin (QV) & $33 / 0$ & Noncropped & Grass & $\mathrm{NI}$ & - \\
\hline Idaho NT (INT) & $10 / 0$ & 7 years wheat & Wheat & NT, NI & nd \\
\hline Idaho CT (ICT) & $24 / 0$ & 7 years wheat & Wheat & $\mathrm{CT}, \mathrm{NI}$ & nd \\
\hline Montana (MT) & $17 / 0$ & nd & Wheat & nd & nd \\
\hline Onecho (ONE) & $9 / 3$ & nd & Wheat & RT, NI & nd \\
\hline Klemgard (KLE) & $12 / 0$ & nd & Wheat & RT, NI & nd \\
\hline Reardan (RED) & $12 / 0$ & nd & Wheat & RT, NI & nd \\
\hline Moses Lake (ML) & $13 / 0$ & nd & Wheat & $\mathrm{CT}, \mathrm{I}$ & nd \\
\hline Almota rotation (ALR) & $10 / 0$ & 3 years wheat, 1 year legume & Wheat & RT, NI & nd \\
\hline Colfax (COL) & $16 / 0$ & 3 years wheat & Wheat & RT, NI & nd \\
\hline
\end{tabular}

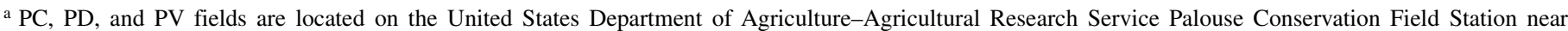
Pullman, WA. The ADB field is on a farm near the Port of Almota, WA. The RD field was conventionally tilled and irrigated and is located on a farm near Ritzville, WA. The LV and LD fields are located on the Washington State University Lind Dryland Research Station near Lind, WA. The LD field is irrigated and has been both conventionally cultivated and direct seeded during its history. Idaho no-till (INT) and conventionally tilled (ICT) fields are located on a farm near Genesee, ID. The MT field is located on a farm near Cascade, MT. The ONE and KLE fields are located on farms between Pullman and the Port of Almota, WA. The ALR field is located near the Port of Almota, WA. The RED, ML, and COL fields are located on farms near these Washington cities.

b Number of $G$. graminis var. tritici isolates/number of Phialophora isolates isolated from each field.

$\mathrm{c}$ nd $=$ Not determined.

${ }^{\mathrm{d}}$ Management practices: $\mathrm{CT}=$ conventional tilled, $\mathrm{RT}=$ reduced till, $\mathrm{NT}=$ no-till, $\mathrm{NI}=$ nonirrigated, and $\mathrm{I}=$ irrigated.

e LDP isolates were from wheat plants within distinct patches. 
tionally cultivated, and was in continuous wheat for three years but had a history of wheat prior to this. The Lind TAD (LD) and virgin (LV) fields are located on the WSU Lind Dryland Research Station. The Lind TAD field had been cropped to irrigated wheat for 39 years and has been both direct seeded and conventionally cultivated during its history. The LV site has never been cropped and is located $\approx 100 \mathrm{~m}$ from the Lind TAD field. The Quincy virgin $(\mathrm{QV})$ site is located near Quincy, WA and has never been cropped. The Idaho no-till (INT) and conventionally tilled (ICT) fields are located on a farm near Genesee, ID. The Montana (MT) field is located on a farm near Cascade, MT. The Onecho (ONE) and Klemgard (KLE) fields are located on farms between Pullman and the Port of Almota, WA. The Reardan (RED), Moses Lake (ML), and Colfax (COL) fields are located on farms near these Washington cities.

A baiting method was used to isolate G-P complex fungi from wheat and grass roots as previously described (14). Briefly, roots from the field were sprayed with tap water to remove soil particles and then they were blotted dry between paper towels. Roots from a single plant were excised, rolled into a ball, and positioned on the top of a $6-\mathrm{cm}$ column of autoclaved vermiculite inside of a plastic tube (15 cm long, $2.5 \mathrm{~cm}$ in diameter) (Stuewe and Sons Inc., Corvallis, OR). The ball of roots was covered with a 1-cm layer of vermiculite and then three wheat seeds (cv. Penawawa) were sown and covered with a 1-cm layer of vermiculite. Roots from about 30 to 50 individual, randomly selected plants from a field were assayed by the baiting method. Each tube was watered $(12 \mathrm{ml})$ and covered with a plastic bag until the plants emerged. The tubes (100 tubes/rack) were placed in a growth room at $16^{\circ} \mathrm{C}$ with a 16 -h photoperiod. Tubes received 12 $\mathrm{ml}$ of water twice a week and one-third-strength Hoagland's nutrient solution (macro-elements only) once a week. After 3 to 8 weeks, plants were removed from the tubes; the roots were washed and then inspected for take-all lesions. Pieces of roots were surface disinfested by submersion in a solution of $0.5 \%$ $\mathrm{AgNO}_{3}$ for $1 \mathrm{~min}$, rinsed three times in sterile deionized water, and drained briefly on autoclaved Whatman no. 1 filter paper (Whatman Inc., Florham Park, NJ). The roots were then cut into segments (5 to $10 \mathrm{~mm}$ ) with and without dark lesions and placed on R-PDA. Plates were incubated in the dark (up to 2 weeks) at room temperature until hyphae grew out from the roots. Hyphae of putative G-P complex fungi were selected based on colony characteristics and the ability to change the color of the medium from orange to purple. The isolates were then subcultured on $1 / 5 \times$ PDA and stored as described above.

DNA extraction and PCR. To prepare DNA for PCR, G-P complex isolates were obtained essentially as previously described (14). Isolates were grown in $1 / 5 \times \mathrm{PDB}$ in 1.5 -ml tubes for 7 days at $23^{\circ} \mathrm{C}$ with shaking $(150 \mathrm{rpm})$. The mycelium was harvested by centrifugation $(5,000 \mathrm{rpm}, 5 \mathrm{~min})$ and then washed twice in sterile deionized water. DNA was extracted using a FastDNA Kit (Bio101, Carlsbad, CA) (23). The final elution volume was $100 \mu \mathrm{l}$ for each DNA sample. DNA was amplified using G. graminis variety-specific primers NS5 and GGT-RP (9), which are specific for rDNA of varieties tritici and avenae. The PCR reaction volume $(50 \mu \mathrm{l})$ contained a $0.2-\mathrm{mM}$ dNTP mixture, $2 \mathrm{mM} \mathrm{MgCl}_{2}, 10 \mu \mathrm{l}$ of $5 \times$ Green GoTaq Flexi buffer (Promega Corporation, Madison, WI), $0.4 \mu \mathrm{M}$ each primer, $50 \mathrm{ng}$ of DNA, and 1 unit of Taq polymerase (Promega Corporation). PCR was performed with an MJ Research PTC-200 thermal cycler (BioRad, Hercules, CA) and consisted of an initial denaturation step at $95^{\circ} \mathrm{C}$ for $5 \mathrm{~min}$ followed by 35 amplification cycles, including denaturation at $95^{\circ} \mathrm{C}$ for $45 \mathrm{~s}$, annealing at $52^{\circ} \mathrm{C}$ for $1 \mathrm{~min}$, and extension at $72^{\circ} \mathrm{C}$ for 1 min. After 35 cycles, samples were incubated at $72^{\circ} \mathrm{C}$ for $10 \mathrm{~min}$ for complete extension. PCR amplicons were visualized by gel electrophoresis in $1.5 \%$ agarose. A single 410-bp PCR fragment indicated G. graminis var. tritici, a single 310-bp fragment indicated var. avenae, and no
PCR product indicated $G$. graminis var. graminis or another genus (9).

An avenacinase-like gene was amplified with G. graminis variety-specific avenacinase-like gene primers (26). Varieties were identified based on different PCR amplicons sizes: $617 \mathrm{bp}$ for G. graminis var. avenae, $870 \mathrm{bp}$ for var. tritici, and 1,086 bp for var. graminis. The PCR reaction volume $(50 \mu \mathrm{l})$ contained 25 pmol of each of the three variety-specific $5^{\prime}$ primers $(G g a, G g g$, and $G g t$ ) and 75 pmol of the $3^{\prime} \mathrm{AV} 3$ primer. An initial denaturation step at $95^{\circ} \mathrm{C}$ for 5 min was followed by 35 amplification cycles consisting of denaturation at $95^{\circ} \mathrm{C}$ for $45 \mathrm{~s}$, annealing at $64^{\circ} \mathrm{C}$ for $45 \mathrm{~s}$, and extension at $72^{\circ} \mathrm{C}$ for $2 \mathrm{~min}$. PCR amplicons were visualized by gel electrophoresis in $1.2 \%$ agarose.

For sequencing, DNA was prepared from unknown G-P complex isolates ADB24, ADB25, ADB26, PD3, PD13, and PD17 and four known strains of G. graminis var. tritici (ADB15, PD19, R3-111a-1, and ARS-A1). PCR conditions for amplification of the ITS region were as previously described (2). Briefly, primers psnDNA2p and pITS4 were used to amplify a conserved sequence of fungal $18 \mathrm{~S}$ and $28 \mathrm{~S}$ rDNA, which included ITS1, 5.8S rDNA, and ITS2 $(\approx 650 \mathrm{bp})$. Primers AV1 and AV3 were used to amplify $\approx 1.3$-kb portions of the avenacinaselike gene. Amplification reactions were carried out in a $50-\mu 1$ volume that contained $25 \mathrm{pmol}$ of each primer, $10 \mu \mathrm{l}$ of $5 \times$ standard polymerase buffer (Promega Corporation), $0.2 \mathrm{mM}$ dNTP mixture (Invitrogen Corp., San Diego, CA), $2 \mathrm{mM} \mathrm{MgCl} 2$, and $1.25 \mathrm{U}$ of Taq DNA polymerase (Promega Corporation). Cycling conditions were $95^{\circ} \mathrm{C}$ for $5 \mathrm{~min}$ as an initial denaturation step and then $95^{\circ} \mathrm{C}$ for $45 \mathrm{~s}, 54^{\circ} \mathrm{C}$ for $30 \mathrm{~s}$, and $72^{\circ} \mathrm{C}$ for $1 \mathrm{~min}$ ( 35 cycles), followed by a 10 -min extension at $72^{\circ} \mathrm{C}$. The quality of the PCR amplicons was checked by electrophoresis in a $1.2 \%$ agarose gel.

Phylogenetic analysis. We performed direct sequencing of the PCR products in both directions. Sequencing was done on an ABI 377 sequencer according to the manufacturer's protocol (ABIPrism, Foster City, CA). Reactions were cleaned using DTR gel filtration cartridges (EdgeBio, Gaithersburg, MD) and then sequenced at the Center for Integrated Biotechnology, Bioinformatics Core Facility, Washington State University, Pullman. The resulting data were analyzed for homologies with previously reported sequences in the National Center for Biotechnology Information (NCBI) GenBank database. DNA sequences were aligned using ClustalW2 (http://www.ebi.ac.uk) (15). Phylogenetic trees were generated with TreeView version 1.6.6 (22) and a neighbor-joining algorithm was used to generate the trees. Trees were constructed using the original data set and 1,000 bootstrap data sets.

Included in the analyses were ITS sequences from the following strains: Phialophora spp.; G. graminis var. tritici T2, T5, R1, R11/17, AT1, and AT2; G. graminis var. graminis G1 and G2/3; $G$. graminis var. avenae A1 and A3; G. incrustans I1 and I3; $G$. cylindrosporus; and Phialophora graminicola (two isolates) (Table 2).

Also included were avenacinase-like gene sequences from the following strains: G. graminis var. tritici $\mathrm{CH} 1, \mathrm{M} 1, \mathrm{CB} 1$, and ATCC28230; G. graminis var. graminis ATCC12761; and $G$. graminis var. avenae ATCC15419 (Table 2). ITS and avenacinaselike gene sequences of isolates determined in this study were deposited at the NCBI database (Table 2).

Pathogenicity tests. The pathogenicity of selected G-P complex isolates was determined using the tube assay described above except that the ball of roots was replaced with either two 9-mmdiameter plugs from a $1 / 5 \times$ PDA culture of the test isolate or three oat kernels colonized by an isolate (14). Strain R3-111a-1 and isolates PD7, PD14, PD17, ADB19, ADB24, and ADB25 were tested on wheat (cv. Penawawa), barley (cv. Baronesse), wild oat, and oat (cvs. Mondia and Otana). To prepare oat kernel inoculum, $250 \mathrm{ml}$ of oat grain and $300 \mathrm{ml}$ of water were mixed in a 1-liter 
flask and then the oat grain was autoclaved on two consecutive days as previously described (20). Each flask was inoculated with a G. graminis var. tritici or unknown G-P complex isolate grown on $1 / 5 \times$ PDA for 7 days. A single plate was cut into small pieces and added to a flask. After 3 weeks of incubation at $23^{\circ} \mathrm{C}$, the colonized oat grain was removed from the flasks, dried for $48 \mathrm{~h}$ under a sterile airflow, and then stored at $4^{\circ} \mathrm{C}$.
Morphological characterization. Wheat seed (cv. Penawawa) was germinated for 2 days on wet filter paper in petri dishes and then placed on the surface of isolates growing on $1 / 5 \times$ PDA. The outer layers of coleoptiles were observed for 10 days for the appearance of hyphopodia $(16,31)$.

Hirsute sclerotia production was tested on wheat leaf extract agar (WLA) (17). Green wheat leaves (100 g) from 4-week-old

TABLE 2. Fungal isolates and DNA sequence information

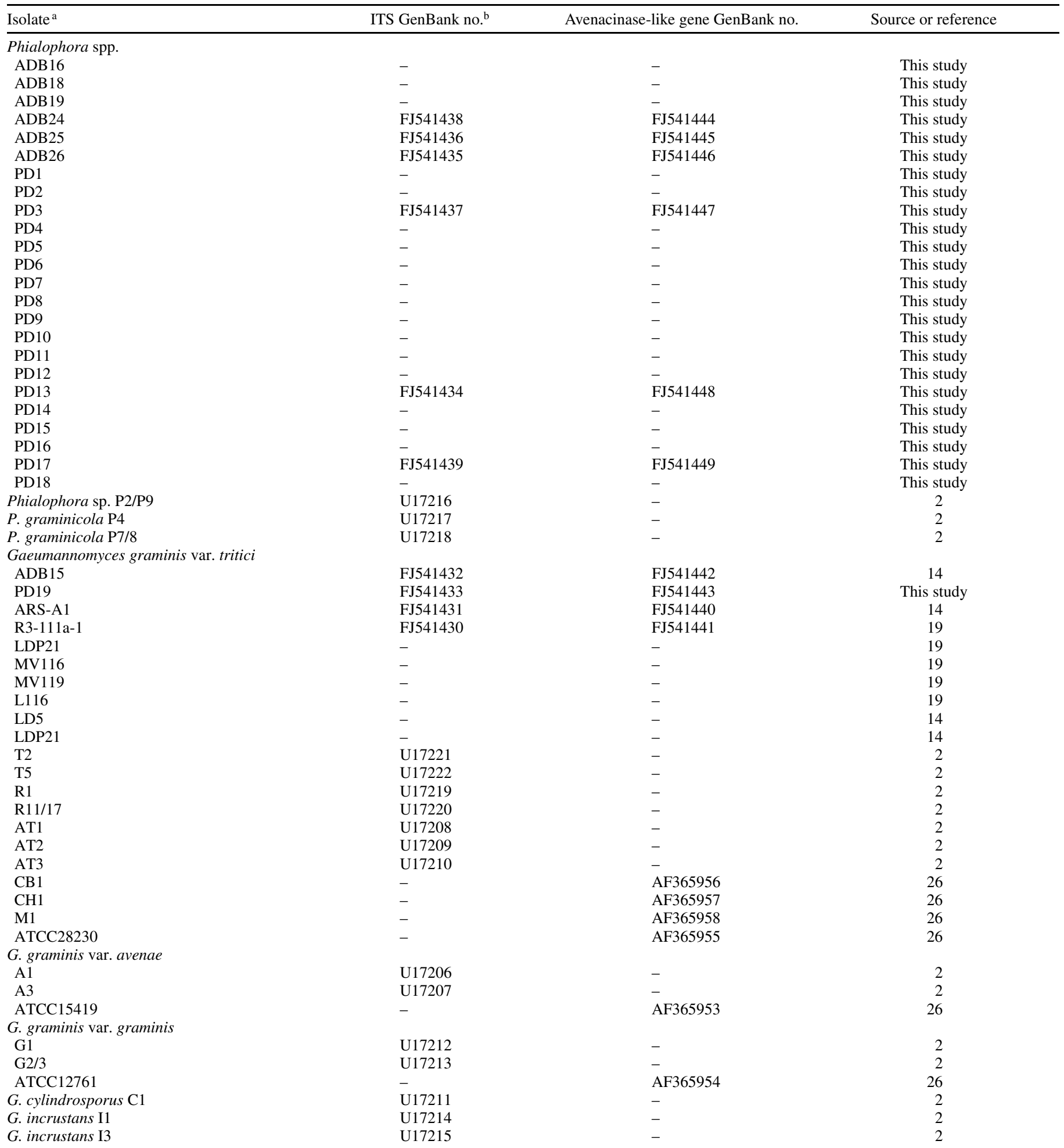

${ }^{\mathrm{a}} \mathrm{ADB}=$ isolates are from a farm near the Port of Almota, WA. The field is nonirrigated, was cropped to corn ( 7 years) followed by wheat (4 years) and has been direct seeded (no-till) for $>20$ years. PD = isolated from the United States Department of Agriculture-Agricultural Research Service Palouse Conservation Field Station, Pullman, WA. The field is nonirrigated and was cropped to wheat or barley and direct seeded for 22 years.

${ }^{\mathrm{b}}$ ITS $=$ internal transcribed spacer; $-=$ not sequenced 
plants were boiled in 1 liter of distilled water for $10 \mathrm{~min}$. The liquid was filtered through two layers of cheesecloth and adjusted to a volume of 1 liter. Agar (20 g) was added and then the medium was autoclaved. A 4-mm-diameter agar plug was cut from the margin of a 1-week-old culture of an isolate on $1 / 5 \times$ PDA. The plug was transferred to WLA and incubated at $23^{\circ} \mathrm{C}$ in the light.

To detect phialospore production, a 4-mm-diameter agar plug from an isolate grown on $1 / 5 \times$ PDA was added to $0.5 \mathrm{ml}$ of $1 / 5 \times$ $\mathrm{PDB}$ in a $1.5-\mathrm{ml}$ tube and then incubated at $23^{\circ} \mathrm{C}$ in the dark for as long as 10 days (1). Phialides and phialospores were observed at $\times 40$ and $\times 100$ magnifications with an Olympus BX41TF microscope (Olympus, Center Valley, PA).

Interaction between an unknown G-P complex isolate and G. graminis var. tritici in soil. G. graminis var. tritici isolates LD5 and LDP21 were tested alone or in combination with representative unknown G-P complex isolate PD17 in the tube assay for ability to cause take-all on wheat (cv. Penawawa). Each isolate was introduced into a raw Shano sandy loam (25) (QV soil) as oat-kernel inoculum (1\% wt/wt), which was sieved, and particle sizes of 0.25 to $0.50 \mathrm{~mm}$ were collected (20). In the tube assay described above, the wad of roots was replaced with $15 \mathrm{~g}$ of soil amended with inoculum. After sowing, $12 \mathrm{ml}$ of water supplemented with metalaxyl (2.5 mg of active ingredient per milliliter) (Novartis, Greensboro, NC) was added to each tube to suppress indigenous Pythium spp. that can cause damping-off. Each treatment was replicated five times with a replicate consisting of five individual tubes, each sown with three seeds. The experiment was arranged in a randomized block design. After 4 weeks of incubation in a growth room as described above, plants were harvested, roots were washed, and disease severity was evaluated based on a 0 -to- 8 scale $(0=$ healthy, $8=$ dead or nearly so) $(14,21)$ and the height of the shoots were measured.

In vitro 2,4-DAPG sensitivity assay. Unknown G-P complex isolates were tested for sensitivity to 2,4-DAPG (Toronto Research Chemicals Inc., Toronto) in an agar plate bioassay as previously described $(14,19)$. To each cell of six-well culture plates (Corning Inc., Corning, NY), $5 \mathrm{ml}$ of 1/5× PDA amended with 2,4-DAPG dissolved in methanol at either $0,2.13,4.57,10$, 21.3, or $45.7 \mu \mathrm{g} \mathrm{ml}^{-1}$ was added. A 4-mm-diameter agar plug from the edge of a 1-week-old culture of an isolate was placed with the mycelium facing down in the center of each 36-mm-diameter cell. Radial growth of each isolate was measured daily in four different directions from the center of the plug to the edge of the mycelium at 3 to 7 days after inoculation. Growth measurements were converted to percent growth inhibition by comparing growth on $1 / 5 \times$ PDA amended with 2,4-DAPG to that on medium with no antibiotic (control, methanol only). Measurements taken at day six were used for the final analysis of growth inhibition and to determine $\mathrm{ED}_{90}$ values.

Statistical analysis. For data from disease assays, statistical analyses were performed using analysis of variance, and means of multiple comparisons were separated by the least significant difference (LSD) test $(P=0.05)$ using Statistix 9.0 (Analytical Software, St. Paul, MN). To determine $\mathrm{ED}_{90}$ values, data from the 2,4-DAPG sensitivity assay were transformed to probits and linear regression was performed on transformed inhibition data versus 2,4-DAPG concentration using SigmaPlot 8.0 (SPSS Inc, Chicago). Points from all four replicates were pooled (24 points:
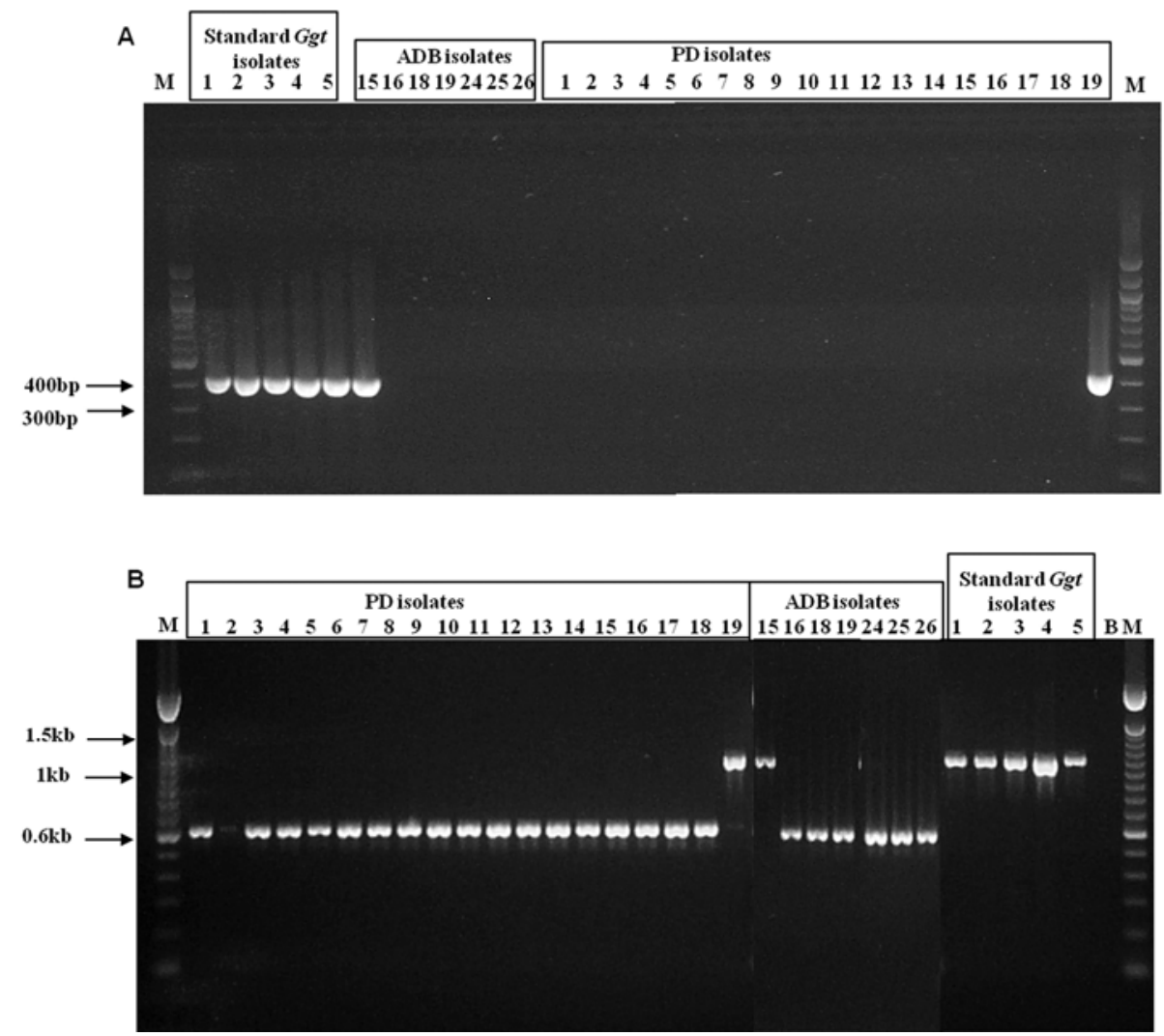

Fig. 1. A, Amplification of DNA from Gaeumannomyces-Phialophora (G-P) complex isolates with Gaeumannomyces graminis variety-specific primers NS5 and GGT-RP. An amplicon of $\approx 410$ bp indicates $G$. graminis var. tritici and a 310-bp amplicon reportedly indicates G. graminis var. avenae (9). No polymerase chain reaction (PCR) product indicates G. graminis var. graminis or a genus other than Gaeumannomyces. Lane M contained a 100-bp DNA ladder as a molecular weight standard. Visualization was by gel electrophoresis in 1.5\% agarose. B, Amplification of DNA of G-P complex isolates with a mix of avenacinase-like gene primers. An amplicon of $\approx 870$ bp was reported to indicate G. graminis var. tritici and a 617-bp PCR product reportedly indicated G. graminis var. avenae. Lane M contained a 1-kb DNA ladder as a molecular weight standard. Visualization was by gel electrophoresis in 1.2\% agarose. ADB, Almota take-all decline (TAD) isolates; PD, Pullman TAD isolates. Standard G. graminis var. tritici (Ggt) isolates 1, ARS-A1; 2, R3-111a-1; 3, MV116; 4, MV119; and 5, L116. 
4 replicates $\times 6$ doses) to run the regression. $\mathrm{ED}_{90}$ values were calculated from the predicted regression equation.

\section{RESULTS}

Distribution and frequency of G-P complex isolates. In total, 362 isolates with cultural characteristics typical of G-P complex fungi were recovered by baiting from the roots of grasses and wheat collected from 18 cropped or noncropped sites in Washington, Idaho, and Montana. Isolates of G. graminis var. tritici collected from PC, RD, LD, Lind TAD patch (LDP), LV, and ADB fields were previously described (14). PCR with NS5 and GGT-RP primers amplified a 410-bp product with DNA from 335 of the 362 isolates $(92.5 \%)$, which is indicative of G. graminis var. tritici (14). Of the 18 sites, 3 (PD, ADB, and ONE) yielded 27 unknown G-P complex isolates whose DNA produced no PCR amplicons with the primers (Fig. 1A), indicating that they were not $G$. graminis var. tritici. These unknown isolates comprised $94.7,25.0$, and $25.0 \%$ of the total number of G-P complex isolates from $\mathrm{PD}, \mathrm{ADB}$, and $\mathrm{ONE}$, respectively, and are the focus of this study.

Morphological characteristics of G-P complex isolates. Known G. graminis var. tritici strains and unknown G-P complex isolates had similar cultural characteristics. Most of them had similar growth rates on $1 / 5 \times$ PDA, were gray to dark gray in color, and all caused a change in the color of R-PDA from orange to purple. Of the 24 unknown G-P complex isolates collected from the ADB and PD fields, 17 were tested for production of hyphopodia. All produced lobed hyphopodia on wheat coleoptiles, whereas known strains of $G$. graminis var. tritici produced simple hyphopodia (Table 3; Fig. 2). Hyphopodia of the unknown isolates were much thicker and larger than those produced by $G$. graminis var. tritici.

Of 13 representative unknown G-P complex isolates tested, all produced phialides and phialospores in $1 / 5 \times$ PDB. Phialides developed laterally from hyphae and phialospores were hyaline and ovoid in shape (Fig. 3). Of 23 unknown G-P isolates tested, 20 isolates produced hirsute structures (sclerotia) on WLA 2 to 3 weeks after inoculation, whereas known isolates of G. graminis var. tritici failed to produce hirsute sclerotia (Fig. 4; Table 3). Collectively, our results indicated that the unknown G-P complex isolates were putative Phialophora spp.

Analysis of the ITS sequence from G. graminis var. tritici and unknown G-P complex isolates. A complete sequence of the ITS1-5.8S-ITS2 rDNA region of rDNA from $G$. graminis var. tritici and unknown G-P complex isolates were amplified with primers psnDNA2p and pITS4 (2), yielding a single fragment of $\approx 650$ bp (data not shown). An alignment of 10 rDNA sequences, 6 from the unknown G-P complex isolates and 4 from G. graminis var. tritici, had $99 \%$ sequence similarity (Fig. 5A). All six unknown G-P complex isolates, from two separate fields (PD and $\mathrm{ADB})$, had identical rDNA sequence and the exact same sequence

TABLE 3. Polymerase chain reaction (PCR) results, sensitivity to 2,4-diacetylphloroglucinol (2,4-DAPG), and morphological characteristics of isolates

\begin{tabular}{|c|c|c|c|c|c|}
\hline \multirow[b]{2}{*}{ Isolate $^{\mathrm{a}}$} & \multicolumn{2}{|c|}{ PCR amplicon size } & \multirow[b]{2}{*}{$\mathrm{ED}_{90}\left(\mu \mathrm{g} \mathrm{ml}^{-1}\right)^{\mathrm{d}}$} & \multirow[b]{2}{*}{ Sclerotia $^{\mathrm{e}}$} & \multirow[b]{2}{*}{ Hyphopodium $^{\mathrm{f}}$} \\
\hline & Variety-specific ${ }^{b}$ & NS5 \& GGT-RPc & & & \\
\hline \multicolumn{6}{|c|}{ Phialophora spp. } \\
\hline ADB 16 & $617 b p$ & $\mathrm{~ns}$ & 26.89 & Produced & - \\
\hline ADB 18 & $617 b p$ & $\mathrm{~ns}$ & 25.45 & Produced & - \\
\hline ADB19 & $617 b p$ & $\mathrm{~ns}$ & 20.31 & Produced & Lobed \\
\hline ADB24 & $617 b p$ & ns & 48.19 & Produced & Lobed \\
\hline ADB25 & $617 b p$ & $\mathrm{~ns}$ & 25.93 & Produced & Lobed \\
\hline ADB26 & $617 \mathrm{bp}$ & $\mathrm{ns}$ & - & Produced & Lobed \\
\hline PD1 & $617 b p$ & $\mathrm{~ns}$ & - & - & - \\
\hline PD2 & $617 b p$ & $\mathrm{~ns}$ & - & Not produced & Lobed \\
\hline PD3 & $617 b p$ & $\mathrm{~ns}$ & - & Not produced & Lobed \\
\hline PD4 & $617 b p$ & ns & - & Produced & - \\
\hline PD5 & $617 \mathrm{bp}$ & $\mathrm{ns}$ & - & Produced & Lobed \\
\hline PD6 & $617 b p$ & $\mathrm{~ns}$ & 21.75 & Produced & Lobed \\
\hline PD7 & $617 \mathrm{bp}$ & ns & 19.10 & Produced & Lobed \\
\hline PD8 & $617 b p$ & $\mathrm{~ns}$ & 15.41 & Produced & Lobed \\
\hline PD9 & $617 b p$ & $\mathrm{~ns}$ & 15.77 & Produced & Lobed \\
\hline PD10 & $617 b p$ & ns & 22.36 & Produced & Lobed \\
\hline PD11 & $617 b p$ & $\mathrm{~ns}$ & 23.92 & Produced & - \\
\hline PD12 & $617 b p$ & ns & 22.40 & Produced & - \\
\hline PD13 & $617 b p$ & $\mathrm{~ns}$ & 30.47 & Not produced & Lobed \\
\hline PD14 & $617 b p$ & ns & 11.94 & Produced & - \\
\hline PD15 & $617 \mathrm{bp}$ & $\mathrm{ns}$ & 15.41 & Produced & Lobed \\
\hline PD16 & $617 \mathrm{bp}$ & ns & 21.16 & Produced & Lobed \\
\hline PD17 & $617 \mathrm{bp}$ & ns & 21.46 & Produced & Lobed \\
\hline PD18 & $617 \mathrm{bp}$ & ns & 15.92 & Produced & Lobed \\
\hline \multicolumn{6}{|c|}{ Gaeumannomyces graminis var. tritici } \\
\hline ADB15 & $1 \mathrm{~kb}$ & $410 \mathrm{bp}$ & $4.48 *$ & Not produced & Simple \\
\hline PD19 & $1 \mathrm{~kb}$ & $410 \mathrm{bp}$ & 8.25 & Not produced & Simple \\
\hline ARS-A1 & $1 \mathrm{~kb}$ & $410 \mathrm{bp}$ & $5.65^{*}$ & Not produced & Simple \\
\hline R3-111a-1 & $1 \mathrm{~kb}$ & $410 \mathrm{bp}$ & $8.18 *$ & Not produced & Simple \\
\hline
\end{tabular}

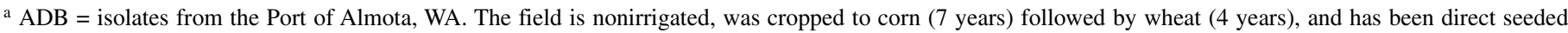
(no-till) for $>20$ years. PD $=$ isolates from the United States Department of Agriculture-Agricultural Research Service Palouse Conservation Field Station, Pullman, WA. The field is nonirrigated and was cropped to wheat or barley and direct seeded for 22 years.

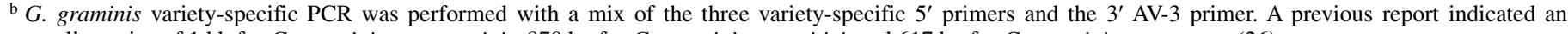
amplicon size of $1 \mathrm{~kb}$ for $G$. graminis var. graminis, $870 \mathrm{bp}$ for G. graminis var. tritici, and 617 bp for G. graminis var. avenae (26).

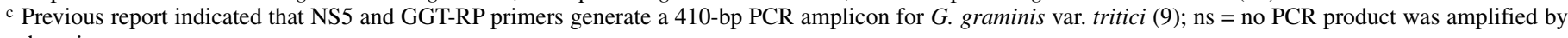
the primers.

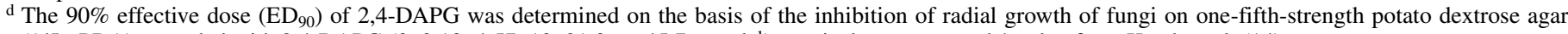
(1/5× PDA) amended with 2,4-DAPG $\left(0,2.13,4.57,10,21.3\right.$, or $\left.45.7 \mu \mathrm{g} \mathrm{ml}^{-1}\right)$; - = isolates not tested; * value from Kwak et al. (14).

e Hirsute sclerotia production was tested on wheat leaf extract agar (WLA) (19). The WLA plates were observed for up to 5 months; $-=$ not tested.

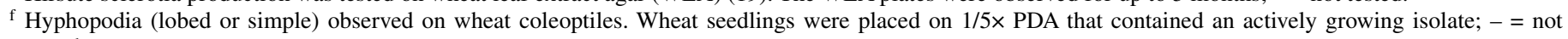
tested. 
as the reference isolates of Phialophora from the United Kingdom (2). The phylogenetic tree generated using a neighbor joining (NJ) algorithm with ClustalW2 and TreeView programs was the same as the tree generated using the parsimony algorithm with PAUP4 (29) (data not shown). These results provided further evidence that the unknown G-P complex isolates were Phialophora spp.

Avenacinase-like gene in Phialophora spp. Rachdawong et al. (26) previously reported that Phialophora spp. do not have an avenacinase-like gene based upon the failure to amplify Phialophora DNA with avenacinase-like gene primers. However, all of our 27 putative Phialophora isolates from the PD, ADB, and ONE fields generated PCR amplicons of $\approx 617$ bp with avenacinase-like gene primers (the three variety-specific $5^{\prime}$ primers and the $3^{\prime}$ AV3 primer) (Fig. 1B) (isolates from the ONE field are not shown).

Alignment of avenacinase-like gene sequences from six putative Phialophora isolates and four strains of G. graminis var. tritici showed less sequence similarity among the isolates than sequences of the ITS region from these isolates described above. Overall similarity of the avenacinase-like gene between isolates of Phialophora spp. and G. graminis var. tritici was 80 to $84 \%$. Among putative Phialophora isolates from the PD field there was 92 to $94 \%$ similarity. Isolates from the ADB field had $93 \%$ similarity. The phylogenetic tree of the avenacinase-like gene showed that putative Phialophora isolates and G. graminis var. tritici were well separated (Fig. 5B). To our knowledge, this is the first report of an avenacinase-like gene in Phialophora spp.

Pathogenicity on cereals. To begin to assess the role of the putative Phialophora isolates in the biology of take-all in Washington State, six representative putative Phialophora isolates from the PD and ADB fields and G. graminis var. tritici strain R3-111a1 were tested for the ability to cause take-all on wheat (cv. Penawawa), barley (cv. Baronesse), wild oat, and two cultivars of oat (cvs. Mondia and Otana). Strain R3-111a-1 caused severe
A
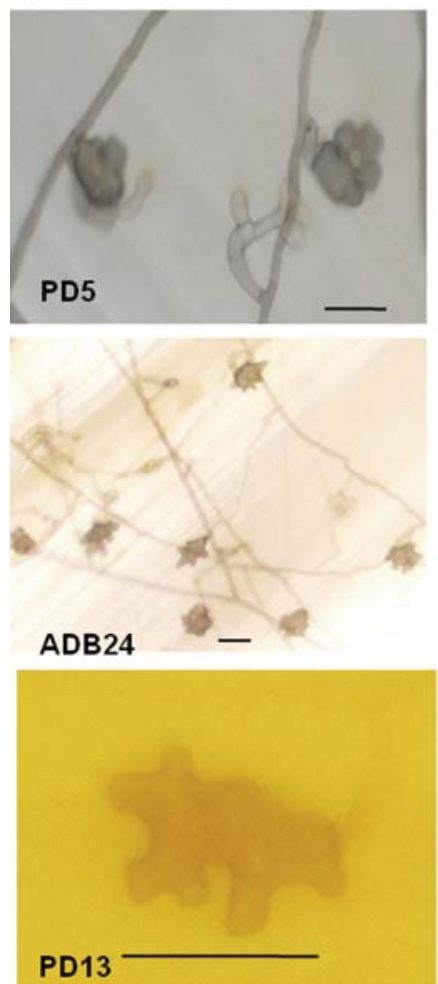

B
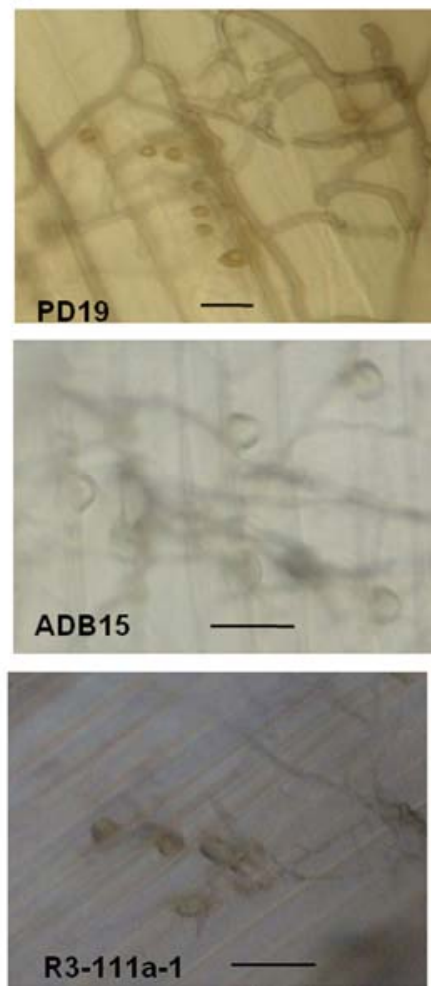

Fig. 2. Hyphopodia on wheat coleoptiles produced by A, unknown Gaeumannomyces-Phialophora complex isolates and $\mathbf{B}$, isolates of Gaeumannomyces graminis var. tritici. Bars indicate $20 \mu \mathrm{m}$. take-all on wheat (disease rating, 7.7) and barley (disease rating, 5.9) but not on the wild or cultivated oat lines, which are known to be resistant to take-all. Nevertheless, characteristic but isolated and nonspreading take-all lesions were detected on oat roots adjacent to colonized oat kernels, the source of the inoculum. The six putative Phialophora isolates caused moderate take-all on wheat roots (disease rating, 3.0 to 4.8 ) and barley roots (disease rating, 2.9 to 5.4 ) but not on oat roots (Fig. 6). However, characteristic isolated take-all lesions were detected on oat roots near the oat-kernel inoculum. Overall, putative Phialophora isolates caused significantly $(P=0.05)$ less damage to wheat and barley than did G. graminis var. tritici strain R3-111a-1 (Fig. 6). Whereas $G$. graminis var. tritici is known to be generally more virulent on wheat than barley, there was a trend for Phialophora to be more virulent on barley than wheat. Generally, putative Phialophora isolates did not spread from the roots to the base of the stems and did not cause wilting and yellowing of leaves as $G$. graminis var. tritici typically does in the tube assay. In another study, of the 24 PD and ADB putative Phialophora isolates, 21 were tested in the tube assay using agar discs as inoculum; 20 of the 21 isolates produced typical take-all lesions (data not shown).

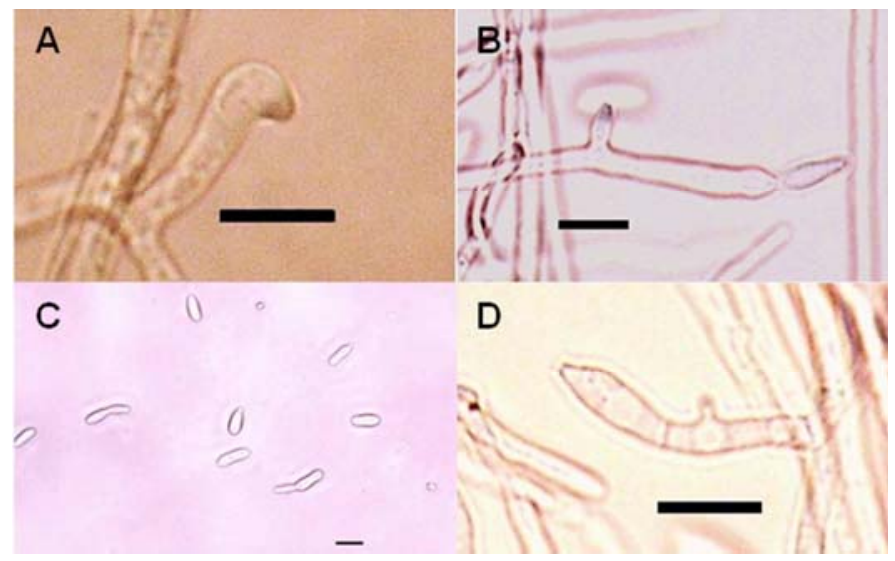

Fig. 3. Phialides and phialospores produced in one-fifth potato dextrose broth by unknown Gaeumannomyces-Phialophora complex isolates. A, Pre-mature phialide; B, phialospore appears on phialide; $\mathbf{C}$, released phialospores; D, phialide after phialospore release. Bars indicate $10 \mu \mathrm{m}$.

A

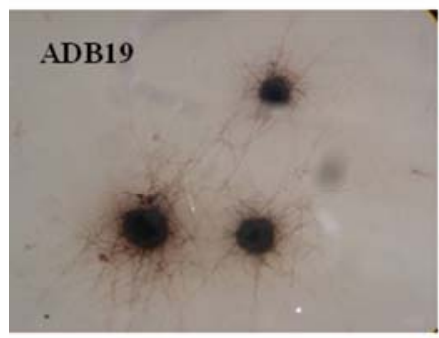

B

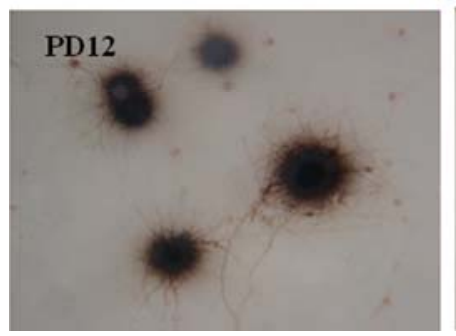

PD19

Fig. 4. Hirsute sclerotia structure formation on wheat leaf extract agar. Plates were incubated in the light at $23^{\circ} \mathrm{C}$ until hirsute structures were produced. $\mathbf{A}$, Unknown Gaeumannomyces-Phialophora complex isolates and $\mathbf{B}$, isolates of Gaeumannomyces graminis var. tritici. 
Interaction of Phialophora and G. graminis var. tritici on wheat. To further understand the role of Phialophora in the takeall-wheat pathosystem in eastern Washington, we determined the amount of take-all that developed on wheat when G. graminis var. tritici strains LD5 or LDP21 were introduced alone and in combination with Phialophora isolate PD17 in the tube assay (14). Both strains of $G$. graminis var. tritici LD5 and LDP21 caused moderate to severe take-all on roots of wheat, with disease ratings of 4.6 and 6.6, respectively. Phialophora isolate PD17 caused mild take-all with a disease rating of 2.2. When a Phialophora isolate and $G$. graminis var. tritici were introduced together, Phialophora isolate PD17 significantly reduced the amount of disease caused by either strain LD5 or LDP21. The disease rating for the treatment with LD5 plus PD17 was 3.2, and for LDP21 plus PD17 was 3.3. The Phialophora isolate plus G. graminis var. tritici treatments had longer shoot length than treatments with $G$. graminis var. tritici alone (Fig. 7). The results of a second independent experiment were similar (data not shown).

Sensitivity of Phialophora spp. to 2,4-DAPG. In all, 18 of the 24 isolates of Phialophora from the PD and ABD fields were tested for sensitivity to 2,4-DAPG in vitro using six-well culture plates. Six isolates (PD1, PD2, PD3, PD4, PD5, and ADB26) were not tested because they grew more slowly than the other Phialophora isolates $(<0.6 \mathrm{~mm}$ per day). All isolates tested grew at a rate of 2.4 to $3 \mathrm{~mm} /$ day (data not shown). Isolates of Phialophora spp. showed a wide variation in sensitivity to 2,4-DAPG: $\mathrm{ED}_{90}$ values were 20.3 to $48.2 \mu \mathrm{g} \mathrm{ml}^{-1}$ for ADB isolates and 11.9 to $30.5 \mu \mathrm{g} \mathrm{ml}^{-1}$ for PD isolates. The average $\mathrm{ED}_{90}$ values for $\mathrm{ADB}$ and PD isolates were 29.4 and $19.8 \mu \mathrm{g} \mathrm{ml}^{-1}$, respectively, and there was a significant difference between isolates from the two fields (LSD $P=0.05$ ) (Table 3). The average $\mathrm{ED}_{90}$ values for $\mathrm{PD}$ isolates and $\mathrm{ADB}$ isolates were significantly greater than $\mathrm{ED}_{90}$ values for all $G$. graminis var. tritici isolates recently reported by Kwak et al. (14).

\section{DISCUSSION}

In Washington State, wheat is grown in a variety of different agroecosystems: west of the Cascade Mountains under high rainfall, in the low-precipitation zone in the center of the state, either under irrigation or in a winter wheat-summer fallow rotation, and under moderate rainfall in the east. Our study builds upon earlier ones conducted during the last 40 years $(12,27)$, demonstrating that the take-all pathogen G. graminis var. tritici is ubiquitous in Washington soils and fields. For example, in some of the driest parts of the state, such as near Quincy (203 mm of annual precipitation) and Lind (254 $\mathrm{mm}$ of annual precipitation), we easily baited $G$. graminis var. tritici from grasses growing in virgin sites that have never been cropped (14). The broad distribution of the pathogen accounts for the occurrence of severe take-all soon after virgin land is cleared and cropped to wheat (3).

Other fungi of the G-P complex known to colonize and infect roots of members of the Poaceae, including roots already infected by the take-all pathogen, have been well described elsewhere $(3,11,13)$. However, we describe here, for the first time, the occurrence in Washington of Phialophora spp. on roots of wheat, especially wheat that has been direct seeded. G. graminis is known to have Phialophora-like anamorphs and these two fungi have many morphological traits in common. For example, $P$. graminicola associated with grasses has G. cylindrosporus as a teleomorphic stage $(4,13)$. Our isolates of Phialophora were first noted because, even though they had colony characteristics similar to G. graminis var. tritici and produced take-all-like symptoms on wheat, the primers NS5 and GGT-RP did not amplify a 410-bp fragment from their DNA. We previously showed (14) that this fragment is amplified from DNA of known isolates of G. graminis var. tritici from Washington State. The isolates of Phialophora had the same host range as $G$. graminis var. tritici, and were moderately virulent on wheat and barley but caused only confined lesions on wild and cultivated oat. Wild oat was tested because it is a major grassy weed in cereal-based cropping systems in Washington State.

Our isolates of Phialophora had morphological characteristics typical of this G-P complex fungus, including production of lobed hyphopodia on wheat coleoptiles, hirsute sclerotia-like bodies, phialides, and phialospores. The average length of the phialospores was $8.6 \mu \mathrm{m}$, which is slightly larger than phialospores previously reported (36). However, Walker (32) reported large variation in the length of phialospores among isolates. Phylogenetic analysis of ITS sequences of G. graminis var. tritici and Phialophora spp. showed that our Phialophora isolates separated from G. graminis and clustered with known Phialophora spp. (Fig. 5A).

It was reported (26) that the three varieties of G. graminis could be distinguished based upon different sizes of PCR amplicons generated with three variety-specific avenacinase-like gene primers (Gga, Ggg, and Ggt) and the 3' primer (AV3). In that study (26), the failure to amplify Phialophora DNA led to the conclusion that Phialophora spp. do not have an avenacinase-like gene and that the primers were specific for $G$. graminis varieties. We tested the

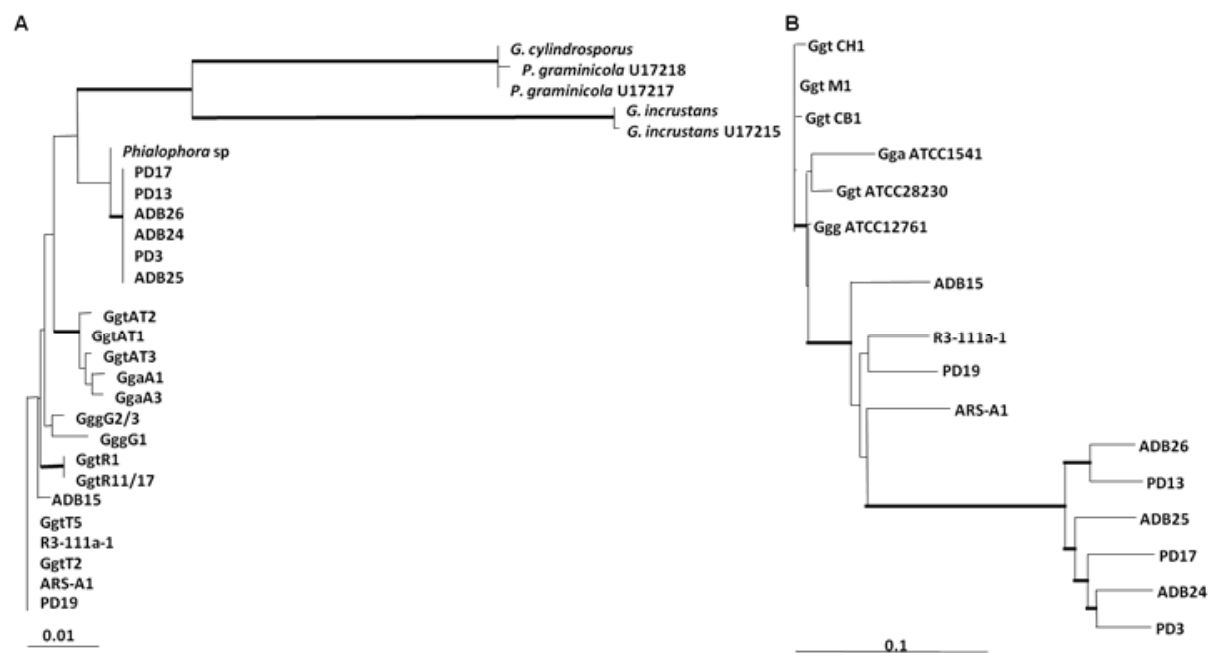

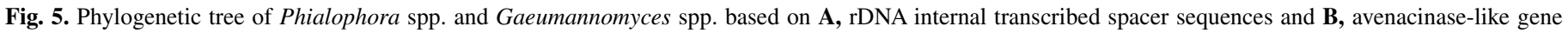

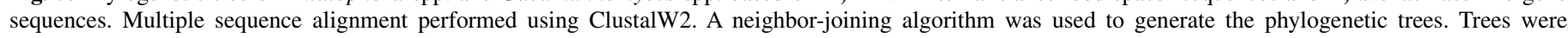
constructed using the original data set and 1,000 bootstrap data sets. Thick line indicates bootstrap score $>850$. 
primers with our isolates of Phialophora and, surprisingly, all of them generated a PCR product of $\approx 610 \mathrm{bp}$ (Fig. 1B). Analysis of the partial sequences of the avenacinase-like genes showed an overall similarity of 80 to $84 \%$ among sequences from Phialophora and G. graminis. Isolates of Phialophora from the PD and ADB fields had 92 to 94 and $93 \%$ sequence similarity, respectively. Variation in the avenacinase-like gene among isolates of Gaeumannomyces and Phialophora indicates that these sequences should be useful in population biology studies of G-P complex isolates. Results from pathogenicity tests with oat as a host indicated that, even though our Phialophora spp. have an avenacinase-like gene, it does not appear to function. A functional gene would be needed to allow significant disease to develop in oat. To our knowledge, this is the first report of an avenacinase-like gene in Phialophora spp.

We baited G-P complex isolates from fields in central and eastern Washington that had different management practices and cropping histories. G. graminis var. tritici was isolated from all
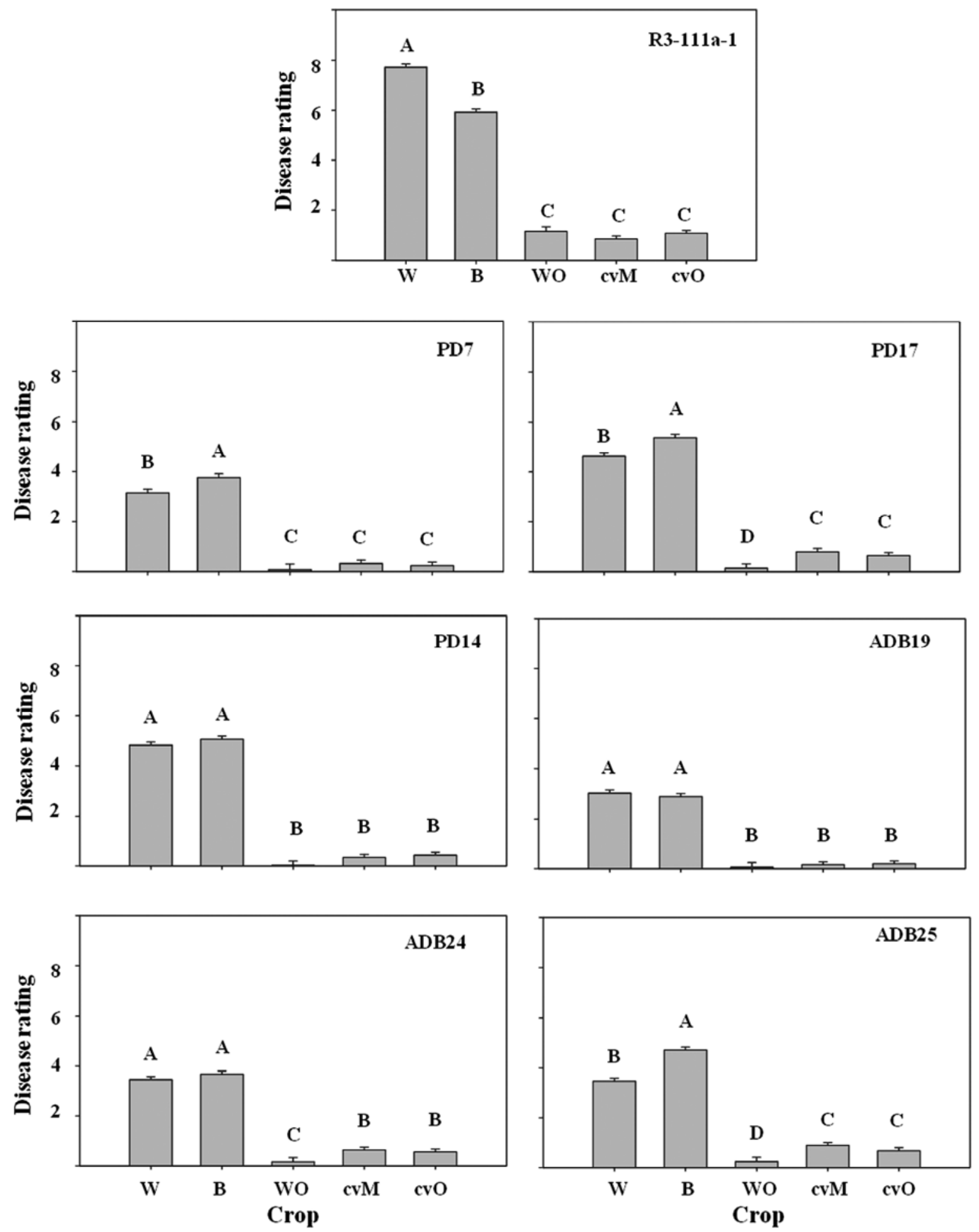

Fig. 6. Take-all symptoms caused by putative Phialophora spp. isolates PD7, PD14, PD17, ADB19, ADB24, and ADB25, and Gaeumannomyces graminis var. tritici R3-111a-1. Disease was rated at 4 weeks using a 0-to-8 scale. Bars with the same letter in the same panel are not significantly different according to the least significant difference test $(P=0.05)$. W, wheat (cv. Penawawa); B, barley (cv. Baronesse); WO, wild oat; cvM, oat (cv. Mondia); cvO, oat (cv. Otana). 
sites but Phialophora spp. were rare and found in only three fields. Our results, showing that Phialophora spp. are not readily isolated from wheat, are similar to those of Ulrich et al. (30), who isolated Phialophora isolates from only 6 of 32 locations sampled in Germany. In addition, only 29 of their 957 G-P complex fungi isolated were identified as Phialophora. PD and ADB were direct seeded without any tillage and the ONE had reduced tillage. All three fields are located in the Palouse region of eastern Washington and are rain-fed, with average annual precipitation of $533 \mathrm{~mm}$. At the time the samples were taken, the ADB field had a history of 4 years of continuous direct-seeded wheat following 7 years of direct-seeded corn. The PD field had 22 years of direct-seeded wheat or barley and the ONE field had wheat grown with $\mathrm{v}$ ery reduced tillage. Phialophora isolates composed 25, 95, and $25 \%$ of the G-P complex fungi baited from those fields. Our results also were quite similar to those of Ulrich et al. (30), who found that, when Phialophora isolates occurred at a site, they composed a significant portion (10 to $50 \%$ ) of the G-P complex isolates.

We are now exploring the management practices that promote the buildup of Phialophora spp. and the extent to which direct seeding or reduced tillage may be a factor. Interestingly, Phialophora spp. were not isolated from other fields with similar soil type and precipitation as the PD, ADB, and ONE fields. Currently, $<15 \%$ of all Washington wheat acreage is direct seeded without tillage. We also are especially interested in the role of Phialophora spp. in the biology of take-all and its occurrence throughout wheat fields in Washington State.
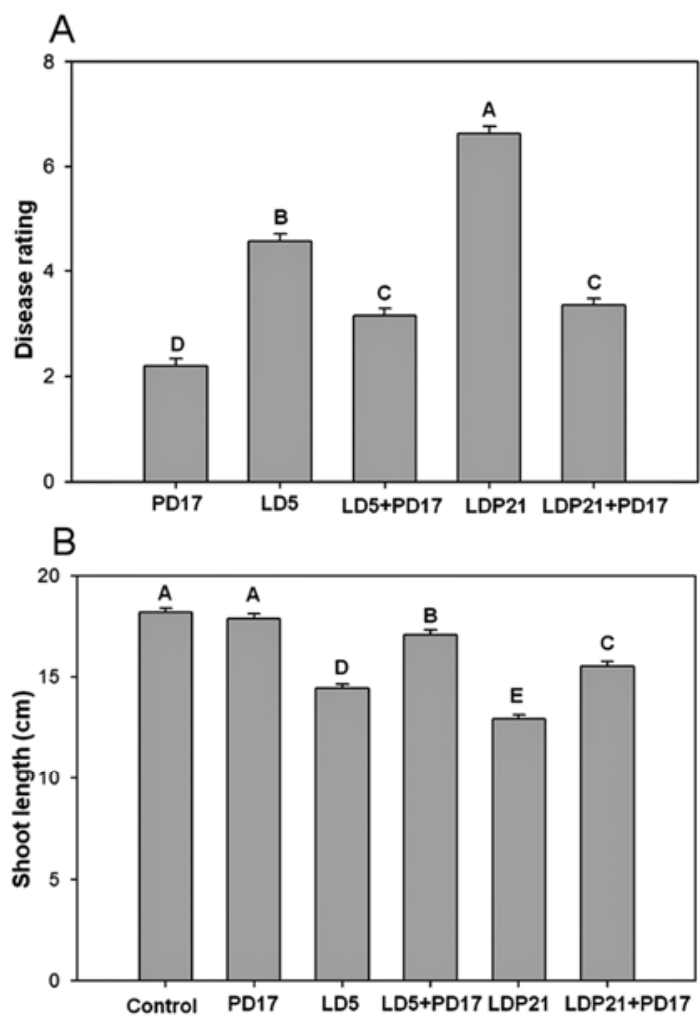

Fig. 7. Take-all on wheat (cv. Penawawa) caused by Gaeumannomyces graminis var. tritici strains LD5 and LD21 alone and in combination with putative Phialophora sp. isolate PD17. G. graminis var. tritici and the Phialophora isolate were introduced into a raw Shano sandy loam (Quincy virgin) as oat-kernel inoculum at a rate of $1 \%$ (wt/wt). After 4 weeks of growth at $16^{\circ} \mathrm{C}$ in a growth room, plants were harvested; $\mathbf{A}$, disease severity was rated based upon a 0 -to- 8 scale $(0=$ healthy and $8=$ dead or nearly so) and B, shoot length was measured. Bars with the same letters are not significantly different according to the least significant difference test $(P=$ 0.05). The control with no inoculum of LD5, LD21, or PD17 had no disease and was not included in the statistical analysis of the disease ratings.
Fungi in the G-P complex that are not pathogens of wheat or barley have been studied extensively $(18,28,35,36)$ worldwide as biocontrol agents of take-all and have been proposed to have a role in take-all decline $(13,18,36)$. For example, Duffy and Weller (6) showed that a G. graminis var. graminis isolate and an avirulent $G$. graminis var. tritici suppressed take-all in studies in the field and under controlled conditions in Washington State. Zriba et al. (36) in Montana and Wong et al. (35) in Australia showed that Phialophora spp. suppressed take-all disease under field conditions. Thus, it is not surprising that our Phialophora isolates, which are much less virulent on wheat and barley than $G$. graminis var. tritici, reduced the severity of take-all when the two fungi were combined in the tube assay. However, it is notable that our Phialophora isolates were substantially less sensitive to 2,4DAPG than our isolates of $G$. graminis var. tritici, with $\mathrm{ED}_{90}$ values of 11.9 to 48.2 and 3.1 to $11.1 \mu \mathrm{g} \mathrm{ml}^{-1}$, respectively. Given the ability of our isolates of Phialophora to suppress take-all and their lower sensitivity to 2,4-DAPG, we now need to explore whether, in some Washington TAD fields (especially those that are direct-seeded), Phialophora spp. may work in concert with 2,4-DAPG producers to suppress take-all. This is an especially interesting possibility for the PD field (24), which has been direct seeded (no-till) with spring or winter wheat or barley for over two decades. Roots of wheat or barley from this TAD field support threshold population sizes of 2,4-DAPG producers required for take-all suppression (24) and $95 \%$ of the G-P complex isolates were Phialophora isolates, with only $5 \%$ G. graminis var. tritici. In contrast, in the PC field, only $50 \mathrm{~m}$ from the PD field, population sizes of 2,4-DAPG producers are below the threshold density required for take-all suppression (14), and all G-P complex fungi isolated were G. graminis var. tritici. We are now focusing our studies on the interaction between Phialophora spp. and $G$. graminis var. tritici in TAD fields as well as on the physiological and molecular basis of the difference in sensitivity of the two G-P complex fungi to 2,4-DAPG.

\section{LITERATURE CITED}

1. Barnett, H. L., and Hunter, B. B. 1998. Pages 88-89 in: Illustrated Genera of Imperfect Fungi. American Phytopathological Society, St. Paul, MN

2. Bryan, G. T., Daniels, M. J., and Osbourn, A. E. 1995. Comparison of fungi within the Gaeumannomyces-Phialophora complex by analysis of ribosomal DNA-sequences. Appl. Environ. Microbiol. 61:681-689.

3. Cook, R. J. 2003. Take-all of wheat. Physiol. Mol. Plant Pathol. 62:73-86.

4. Cook, R. J., Schillinger, W. F., and Christensen, N. W. 2002. Rhizoctonia root rot and take-all of wheat in diverse direct-seed spring cropping systems. Can. J. Plant Pathol. 24:349-358.

5. Duffy, B. K., and Weller, D. M. 1994. A semiselective and diagnostic medium for Gaeumannomyces graminis var. tritici. Phytopathology 84:1407-1415.

6. Duffy, B. K., and Weller, D. M. 1995. Use of Gaeumannomyces graminis var. graminis alone and in combination with fluorescent Pseudomonas spp. to suppress take-all of wheat. Plant Dis. 79:907-911.

7. Elliott, M. L. 1991. Determination of an etiologic agent of bermudagrass decline. Phytopathology 81:1380-1384.

8. Elliott, M. L. 2005. Survival, growth and pathogenicity of Gaeumannomyces graminis var. graminis with different methods of longterm storage. Mycologia 97:901-907.

9. Fouly, H. M., and Wilkinson, H. T. 2000. Detection of Gaeumannomyces graminis varieties using polymerase chain reaction with variety-specific primers. Plant Dis. 84:947-951.

10. Fouly, H. M., Wilkinson, H. T., and Domier, L. L. 1996. Use of random amplified polymorphic DNA (RAPD) for identification of Gaeumannomyces species. Soil Biol. Biochem. 28:703-710.

11. Freeman, J., and Ward, E. 2004. Gaeumannomyces graminis, the take-all fungus and its relatives. Mol. Plant Pathol. 5:235-252.

12. Heim, M., Folwell, R. J., Cook, R. J., and Kirpes, D. J. 1986. Economic benefits and costs of biological control of take-all to the Pacific Northwest wheat industry. Wash. State Univ. Agric. Res. Cent. Res. Bull. 0988.

13. Hornby, D. 1998. Take-All of Cereals. A Regional Perspective. CAB International, Wallingford, UK.

14. Kwak, Y-S., Bakker, P. A. H. M., Glandorf, D. C. M., Rice, J. T., Paulitz, T. C., and Weller, D. M. 2009. Diversity, virulence and 2,4-diacetyl- 
phloroglucinol sensitivity of Gaeumannomyces graminis var. tritici isolates from Washington State. Phytopathology 99:472-479.

15. Larkin, M. A., Blackshields, G., Brown, N. P., Chenna, R., McGettigan, P. A., McWilliam, H., Valentin, F., Wallace, I. M., Wilm, A., Lopez, R., Thompson, J. D., Gibson, T. J., and Higgins, D. G. 2007. ClustalW and ClustalX version 2.0. Bioinformatics 23:2947-2948.

16. Mathre, D. E. 1992. Techniques for selected genera of soilborne fungi. Pages 60-63 in: Methods for Research on Soilborne Phytopathogenic Fungi. L. L. Singleton, J. D. Mihail, and C. M. Rush, eds. American Phytopathological Society Press, St. Paul. MN.

17. Mathre, D. E. 2000. Take-all disease on wheat, barley, and oats. Online. In: Plant Health Progress doi: PHP-2000-0623-01-DG. In: Diagnostic Guides. St. Paul, MN.

18. Mathre, D. E., Johnston, R. H., and Grey, W. E. 1998. Biological control of take-all disease of wheat caused by Gaeumannomyces graminis var. tritici under field conditions using a Phialophora sp. Biocontrol Sci. Technol. 8:449-457.

19. Mazzola, M., Fujimoto, D. K., Thomashow, L. S., and Cook, R. J. 1995. Variation in sensitivity of Gaeumannomyces graminis to antibiotics produced by fluorescent Pseudomonas spp. and effect on biological control of take-all of wheat. Appl. Environ. Microbiol. 61:2554-2559.

20. Ownley, B. H., Duffy, B. K., and Weller, D. M. 2003. Identification and manipulation of soil properties to improve the biological control performance of phenazine-producing Pseudomonas fluorescens. Appl. Environ. Microbiol. 69:3333-3343.

21. Ownley, B. H., Weller, D. M., and Thomashow, L. S. 1992. Influence of in situ and in vitro $\mathrm{pH}$ on suppression of Gaeumannomyces graminis var. tritici by Pseudomonas fluorescens 2-79. Phytopathology 82:178-184.

22. Page, R. D. 1996. TreeView: An application to display phylogenetic trees on personal computers. Comput. Appl. Biosci. 12:357-358.

23. Paulitz, T. C., and Adams, K. 2003. Composition and distribution of Pythium communities in wheat fields in eastern Washington state. Phytopathology 93:867-873.

24. Raaijmakers, J. M., and Weller, D. M. 1998. Natural plant protection by 2,4-diacetylphloroglucinol-producing Pseudomonas spp. in take-all decline soils. Mol. Plant-Microbe Interact. 11:144-152.

25. Raaijmakers, J. M., Weller, D. M., and Thomashow, L. S. 1997. Frequency of antibiotic-producing Pseudomonas spp. in natural environ- ments. Appl. Environ. Microbiol. 63:881-887.

26. Rachdawong, S., Cramer, C. L., Grabau, E. A., Stromberg, V. K., Lacy, G. H., and Stromberg, E. L. 2002. Gaeumannomyces graminis vars. avenae, graminis, and tritici identified using PCR amplification of avenacinaselike genes. Plant Dis. 86:652-660.

27. Ramsey, N. E. 2001. Occurrence of take-all on wheat in Pacific Northwest cropping systems. M.S. thesis, Department of Plant Pathology. Washington State University, Pullman.

28. Speakman, J. B. 1984. Control of Gaeumannomyces graminis var. tritici in wheat by isolates of the G. graminis var. graminis/Phialophora sp. (lobed hyphopodia) complex under field conditions. Phytopathol. Z. 109:188-191.

29. Swofford, D. L. 1998. PAPU*. Phylogenetic Analysis Using Parsimony (*and other methods). Version 4. Sinauer Associates, Sunderland, MA.

30. Ulrich, K., Augustin, C., and Werner, A. 2000. Identification and characterization of a new group of root-colonizing fungi within the Gaeumannomyces-Phialophora complex. New Phytol. 145:127-135.

31. Walker, J. 1980. Gaeumannomyces, Linocarpon, Ophiobolus and several other genera of scolecospored ascomycetes and Phialophora conidial states, with a note on hyphopodia. Mycotaxon 11:1-129.

32. Walker, J. 1981. Taxonomy of take-all fungi and related genera and species. Pages 15-74 in: Biology and Control of Take-all. M. J. C Asher and P. J. Shipton, eds. Academic Press, London.

33. Weller, D. M. 1988. Biological control of soilborne plant pathogens in the rhizosphere with bacteria. Annu. Rev. Phytopathol. 26:379-407.

34. Weller, D. M., Landa, B. B., Mavrodi, O. V., Schroeder, K. L., De La Fuente, L., Bankhead, S. B., Allende-Molar, R., Bonsall, R. F., Mavrodi, D. V., and Thomashow, L. S. 2007. Role of 2,4-diacetylphloroglucinolproducing fluorescent Pseudomonas spp. in the defense of plant roots. Plant Biol. 9:4-20.

35. Wong, P. T. W., Mead, J. A., and Holley, M. P. 1996. Enhanced field control of wheat take-all using cold tolerant isolates of Gaeumannomyces graminis var. graminis and Phialophora sp. (lobed hyphopodia). Plant Pathol. 45:285-293.

36. Zriba, N., Sherwood, J. E., and Mathre, D. E. 1999. Characterization and effectiveness of Phialophora spp. isolated from a Montana take-all suppressive soil in controlling take-all disease of wheat. Can. J. Plant Pathol. 21:110-118. 